\title{
Antecedent Factors of Competitive Advantage and its Impact on Performance
}

\author{
Irsad Andriyanto $^{1^{*}}$, Jaenal Arifin ${ }^{1}$, and Aulia Ardhian Ayuningtyas ${ }^{2}$ \\ \{irsad.smg@gmail.com* \\ ${ }^{1}$ Department of Sharia and Islamic Economy, IAIN Kudus, Kudus, Indonesia \\ ${ }^{2}$ Department of Management, Cendekia Karya Utama College, Semarang, Indonesia
}

\begin{abstract}
The endurance of small and medium enterprises (SMEs) contributed in each the traditional and modern sectors that successively that affect national development. However, they still encountered a growing challenge, expressly since the Indonesian government signed an agreement with Association of Southeast Asian Nations Economic Community (AEC). The agreement forced small and medium-sized enterprises to form their development and creative thinking amidst serious challenge. The point of this examination was to get a clarification of elements influencing the aggressiveness of SMEs and the impact competitive advantage on business performance. The respondents SME's in Kudus City diagrammatic by the embroidery business owners that since three years before they need fully fledged the decreasing in profit. They expressed their response to research variables like competitiveness, orientation, adaptability, internal resources, and performance. The utilization of structural equation modeling (SEM) was required to inspect the connection among components and the direct/indirect effect from exogenous elements to endogenous elements with the assistance of AMOS programming. The outcomes demonstrated that the capability to evolve to business conditions and internal resource affected their business position. Finally, the pioneering introduction of an entrepreneur, SMEs competitive advantage and internal assets (budgetary, physics, human being and nature) affect the business performance exactly.
\end{abstract}

Keywords: Advantage, Competitive, Entrepreneurship, Resources, Performance.

\section{Introduction}

The number of Small and Medium-sized Enterprises (SMEs) raises in many countries in line with the contribution to poverty alleviation since their commitment to financial advancement. Their commitment to the economic process is seen from its result on desperation facilitating (job creation, serves various needs, and financial support), income distribution, and its responsibility to raise up national GDP. SMEs were continuous growing in abundance, but were not bankable yet or they have no adequate certifications in funding despite having good characters and performance. Moreover, as per capital problems, they also face obstacles of human resources, business networks, unpredictable business environment, infrastructures, and limited access to the market, whereas low competitiveness takes effect on business sustainability.

Entrepreneurs ought to take advantages from these opportunities aggressively while managing any risks (Covin and Slevin, 1989). They ought to most likely adjust with business uncertainty that forces them to generate long-term plan and strategic basic leadership. Their successfulness is consequences of the ability to adapt with the environmental changes, whereas the ability then affect the basic company's strategy. To implement a strategy that improves business efficiency and effectiveness, a company 
should be able to manage internal resources that contribute to its competitive edge through making its production cost reduce (Seddon et al., 2017).

Since Indonesia government assigned the ASEAN-Economic Community and ASEAN-China Free Trade Agreement the intense competition is felt by especially small business in Kudus (Purnomo et al., 2016). Moreover, SMEs in Central Java, especially in the embroidery business in Kudus City, have an issue with respect to the advancement. The models didn't encounter critical changes throughout the previous 3 years or the models are not ready to meet the market trend. Accordingly, it impacts on the requests decline, which directly affects the profit. This phenomenon needs unique consideration regarding have the business still develops with high competitiveness.

\section{Theoretical Framework}

\subsection{Entrepreneurial Orientation}

High monetary development will be acknowledged whether business foundations develop rapidly. Regarding literature of entrepreneurship, the orientation is widely recognized as the most common constructs that include proactive, the courage to take risks, and innovativeness. Innovativeness is the capacity to apply inventiveness so as to tackle issues and chances to upgrade and enhance expectations for everyday comforts. Risk-taking is an action that is oriented to the opportunities in the uncertainty decision making. Subsequently, proactive is a condition where the leader is capable of identifying opportunities, problems, needs, and changes in the future (Uhl-Bien et al., 2007).

The orientation of entrepreneurship drives an essential occupation for an association to upgrade and be a sufficient noteworthiness of business execution. It is perceived as a corporate advantages procedure to almost certainly contend all the more viably in a similar marketplace. Many companies commonly use these four measurement: extroversion, internal locus of control, self reliance, and need for achievement to achieve that goal (Affendy et al., 2015). The blend of those measurements is accepted to enhance business intensity and performance.

\subsubsection{Entrepreneurial Orientation as a predictor of Competitive Advantage}

Discussion about strategy content (generic strategy) in strategy settlement processes, the orientation seems to be a critical construct to explore. It is essential to be considered in designing and implementing competitive strategies. Subsequently, connecting company strategy to business orientation presents challenges in business research (Lechner and Gudmundsson, 2014). Notice that the orientation of entrepreneurship has pointed as a possible solution to the problems that businesses faced in order to achieve an advancement in competition (Fatoki and Oni, 2014). Thus, understanding of this orientation, especially in SMEs context has a great impact on strengthening business competitiveness (Jantunen et al., 2005). Innovativeness, risktaking, and proactiveness incorporated in business orientation affect company competitiveness through several ways.

\subsubsection{Entrepreneurial Orientation Effect on Performance}

Some researches has disclosed that orientation of entrepreneurship did not influence the performance at all because it has been perceived as a solid indicator of competitiveness. However at this point usually considered as an indicator of business 
development and performance. Due to competition in the present era, SMEs face expanding weight got from rivalry from over the world. They face expanding trouble to keep up and enhance business execution in time except if they can effectively deal with these pressures properly (Affendy et al., 2015).

\subsection{Adaptability}

Adaptability as a form of flexibility is the company ability to modify the approach of an organization or activity given changes in their outer conditions. This is a valuable ability for people and organizations to compete outperform others as a whole (Ismaeel and Blaim, 2012). The challenge with strategic adaptability is that they essentially have to plan for the unexpected. Naturally, they can't predict changes or problems coming from their environment such as business trend, regulation, even disaster. However, they can modify the method/respond with controllable internal business activities.

The raising innovation, investment in technology, and utilizing market-based management lead to highly competitiveness that entrepreneurs should do. Those caused a company achieved the expected business performance. The performance is also influenced by stable political and economic conditions that will contribute a very significant business climate, indicated by the increasing number of small businesses and numerous products be offered. We can conclude that to be able to compete well, a company must have a good quality of adaptation to their business environment (Covin and Slevin, 1989).

Many researcher use non-monetary measurement to examine business performance that impact on difficulty to assess the key factors in business achievement or failure, (Hoque, 2004). Moreover, various perspectives can be used to examine business performance actually, like three-dimensional of business performance consists of effectiveness, efficiency, and adaptability. The first, effectiveness that was considered as the form of products and services comparison with others (Ruekert and Walker, 1987).

Efficiency is recognized as a degree of comparing product/service outputs to a set of inputs resources). In the mean time, accomplishment in reacting to changes is the essence of adaptability (Mouzas, 2006). Explicitly, effectiveness measures how the company goals achieved that closed to nonfinancial measurement, efficiency measures profitability accomplishing which highly correlated to financial measurement, and adaptability is closely in correlation with flexibility toward changes (Miller et al., 2012).

\subsection{Internal Resources}

Prior researches still difficult to make a conclusion the term of resource. Many discussion analyzed in the strategic management literature that resources derived from three main constructs such as capabilities, competencies, and resources. The internal resources refers to the internal environment (a set of company internal factors which in turn affect the success of business operations) controlled by a company. The company has full control over these factors as the opposite of the external environment. However, it is also important for a company to recognize threats outside (Barney, 1991). The better understanding of threats outside company leads to create the strategy that maximizes its resources and minimizes the weaknesses. 
When a company perform good governance of its internal resources and operations, then it can be one of key success factors. Therefore, the important role of leadership force a company having reliable internal resources (Momoh et al., 2010). The style of leadership also impact company to apply certain organizational culture (Kuratko et al., 2014). Financial resource like funding, investment and income sources; physical resources such as location, facilities, and equipment; human resources such as employees and volunteers; natural resources, patents, copyrights, and trademark are other reliable resources that drives to superior position (Abdullah and Hamdan, 2012).

\subsubsection{Internal Resources Effects on Competitive Advantages}

The fundamental aggressive accentuation on most ventures seems to have moved from being product-market based to more resource based management (Etemad, 2009). In line with the resource-based theory, bundles of resources, rather than instead of industry-wide auxiliary qualities or the product-market combinations chosen for their deployment (e.g. strategic conduct), lie at the center of a firm's competitive advantage (Kuratko et al., 2014).

Company access on controllable (possess and exploit) resources lead a company to distinguish from other. To be unique, the company should combine and apply innovation to its resources (product development capabilities), human resource, brand and business experience (production, marketing, sales etc.) as examples of such capabilities. This ability is in turn usually seen as a collection of routine production that is socially complex and therefore tends to oppose imitation. (Kozlenkova et al., 2014).

\subsubsection{Internal Resources Effects on Performance}

A company can reach its superior performance if certain types of resources/assets are well-managed that in turn produce competitive advantages (Gupta and Kumar, 2013). The capital, employees, knowledge, and machines are commonly recognized as company's internal resources that are the basis for achieving reliable superior performance. Internal resources such as capabilities, organizational processes, information, and knowledge are also important to a company in applying its strategy more efficient and effective.

The RBV literature (resource based value) shows that internal resources possess a long-lasting competitive advantage. Entrepreneurs as a corporate resource catalyst have been researched over the past decade (Jackson et al., 2014). Their success is a reflection of business quality, a form of resources collaboration consisting of personality attributes, human capital, environment, and specific company experience. This collaboration is the most common resources to achieve its competitive advantages (Chandler and Hanks, 1994; Clancy Dollinger, 1995; Heru Priyanto, 2012).

\subsection{Competitive Advantage}

Many people equalize competitive advantage with superior performance, but actually they are different because competitive advantage closed to specific context. It remains difficulties to generalize the description and operational construct of competitive advantage even it has widely discussed in strategic management literature. It has several meanings, including the emphasis on the superiority of resources and company expertise. Another definition emphasizes excellence in performance achievement. In order to achieve an excellent position, a company should to focus on 
the utilization of resources it has. The position becomes the company's capital to continue competing with competitors (Johnson et al., 2008).

Company's superior position is a reflection of its competitive advantage that shows its existing position among industries (Irfan et al., 2014), whereas the superiority closely rely on customer perceived value. For an example, when a company able to produce qualified products in expensive price for customers with low purchasing power, then it will not carry a company to competitive position. This means that competitive advantage should be seen thoroughly with the various aspects that surround it.

\subsection{Performance}

The freedom of the owner or manager in making decisions, taking the initiative and setting policy strategies that affect business performance. Prahalad (1990) state that superior position achievement forces a company to consolidate its capabilities into a competence that strengthen individual in the organization to adapt to market changes continuously (Prahalad et al., 1990). Finally, this superior position will take an effect on improving business performance reflected in the increase in sales and stock prices. Moreover, a company will be able to maintain long-term advantages if they have capabilities to meet market demand compared to others (Morrison et al., 2003).

Competitive advantage is used in corporate strategy discussion in case of company performance improvement. Competitiveness sees the company as a whole consisting of many activities carried out by the company in designing, producing, marketing, handing over and supporting sales (Porter and Kramer, 2006). Companies that have a higher level of competitive advantage will also have better business performance (Etemad, 2009).

\section{Discussions}

The respondents were the managers of the embroidery industry in Kudus Regency which consists of 176 companies. They were expressed their perception through a set of questionnaire and subsequently analyzed by structural equation modeling (SEM) with AMOS program. This is a famous tool that believed to investigate the effects of entrepreneurial orientation, adaptability, and internal resource on competitive advantage and the influence on business performance.

Table 1. Hypothesis Testing Results.

\begin{tabular}{cc}
\hline Hypothesis & $\mathrm{CR}$ and P value \\
\hline $\begin{array}{c}\text { Adaptability of the business } \\
\text { environment has a positive effect } \\
\text { on competitive advantage (H1) }\end{array}$ & $\mathrm{H}, 010:(0,035)$ \\
\hline $\begin{array}{c}\text { The company's internal resources } \\
\text { positively influence on }\end{array}$ & $6,219:(0,007)$ \\
competitive advantage (H2) & $\mathrm{H}$ accepted \\
\hline $\begin{array}{c}\text { Entrepreneurial orientation has a } \\
\text { positive influence on competitive } \\
\text { advantage (H3) }\end{array}$ & $1,599:(0,364)$ \\
$\mathrm{H} 1$ rejected \\
\hline $\begin{array}{c}\text { Entrepreneurial orientation has a } \\
\text { positive effect on company }\end{array}$ & $2,603:(0,121)$ \\
\hline
\end{tabular}




\begin{tabular}{cc}
\hline performance (H4) & \\
\hline $\begin{array}{c}\text { The company's internal resources } \\
\text { positively influence the company's } \\
\text { performance (H5) }\end{array}$ & H5 accepted \\
\hline $\begin{array}{c}\text { Competitive advantage positively } \\
\text { influences company performance } \\
\text { (H6) }\end{array}$ & H6 accepted \\
\hline
\end{tabular}

The following discussion explained the results of hypothesis testing from table 1 .

\subsection{Hypothesis 1}

The results corroborated the findings of (Andriyanto and Nurjanah, 2015). A competitive advantage could be achieved if the business actors and their teamwork (employees) had an ability to understand the customer's wishes well, able to recognize the development of competition carefully and have a good working relationship with their suppliers. So that companies can get information, recognize trends and relationships within an organization's external environment, where this adaptability process could help the management in planning future actions.

\subsection{Hypothesis 2}

This research was in line with research conducted by (Jiang et al., 2012), that proves that SMEs internal resources influenced on competitive advantage significantly. It means that the SMEs resources were controllable or the companies had full access to resources usage and control. Well managed internal resources enable companies to implement the right strategies forming competitive advantage. Internal resources were able to provide superior company performance.

\subsection{Hypothesis 3}

The results indicated that entrepreneurial orientation did not affect SMEs competitive advantage (low significance level). Nevertheless, it showed that the influence in the direction with the hypothesis. The explanation is that in an industrial cluster there is uniformity or at least similarity in terms of the resources owned by each company. They owned almost the same information, employee skills, technology, raw materials, and even capital.

The existence of the similarity factor is possibly the cause entrepreneurial orientation had no significant influence on competitive advantage. The phenomenon that occurs in this study is that there is almost no innovation process that occurs so that the existing competitiveness is being lowed

\subsection{Hypothesis 4}

The results were in line with prior research conducted by Avlontis and Salavou (2009) which showed entrepreneurial orientation influenced on company performance (Avlonitis and Salavou, 2007). Likewise with research conducted by Witjaksono (2009) which also shows the same results regarding the entrepreneurial orientation influence on company performance (Witjaksono, 2009). The company leader's ability to implement innovation, being motivated and have the courage to take risks lead products 
to be more innovative and achieve a broader marketplace. The condition helps the company to improve performance.

\subsection{Hypothesis 5}

The results of this study succeeded in supporting the hypothesis that the SMEs internal resources directly take an effect on performance. The results of this study indicate that the performance of embroidered SMEs in Kudus Regency has the ability to increase their potential to improve company performance. The resources consist of many factors that the manager have to recognize and use it as effectively as possible. They also should to perform efficient ways of producing products at prices that are acceptable to the market. If the market responds well, then the performance expected by the company will be achieved.

\subsection{Hypothesis 6}

The results supported previous research conducted by Gupta and Kumar (2013) that competitive advantage influence business performance (Gupta and Kumar, 2013). Kumar et al. (2011) and Boulianne (2007) also stated the same result that competitive advantage affect the company performance (Boulianne, 2007; Kumar et al., 2011). Similar results were obtained from prior research conducted by Othman et al., (2015) (Othman et al., 2015).

The outcomes also supported previous studies by Kumar and Pansari (2006) stated that company competitive advantage has a positive effect on the its marketing performance (Kumar and Pansari, 2016). If a business does not have a unique or different value, then the level of sales, profits and the level of visiting consumers in a business may not be able to increase superiorly (Mariadoss et al., 2011).

The implementations of this results contribute to managerial activities in order to develop embroidery businesses in Kudus Regency. The activities could be conducted by the government and SMEs in terms of strengthen internal resources such technology, employee skills, capital, information, and knowledge.

The following are indicators found that have an effect on company performance: sales growth, customers' growth; profit growth; and market growth. Competitive advantage was affected by all other variables. The following were indicators that affect competitive advantage: uniqueness; not easily replaced; competitive prices; and not easily imitated.

Entrepreneurial orientation becomes important in this study. The following indicators influence the orientation: proactive; innovation; and risk-taking. The following indicators were in the context of adaptability, such as ability to understand customers; ability to work with suppliers; and ability to understand competitors.

\section{Conclusions}

The results provided solutions as the answer of research problem. There are six processes that can be used to improve company performance, namely:

First, company performance can be enhanced by entrepreneurial orientation, including by innovating products, having the courage to take risks, and having a proactive attitude. Entrepreneurial orientation lead a company to raise better performance directly. 
Second, company performance can be improved by adapting to the business environment, particularly by understanding customers' needs, understanding competitors, and good cooperation with suppliers. Adaptation to the business environment will affect the company's performance. In other words, a company must be able to increase flexibility toward environment changes.

Third, company performance can be improved by utilizing internal company resources, including capabilities, information, knowledge of human resources, capital, technology, and employee skills. Companies that are able to utilize their internal resources well will be better at improving their performance. The well managed internal resources lead a company to the better performance.

Fourth, company performance can be improved by entrepreneurial oriented ways, where the entrepreneurial orientation that is carried out will increase the company's competitive advantage. Competitive advantages possessed will improve company performance

Fifth, the company's performance can be improved by adapting to the business changes, where the adaptation to these changes will improve the company's competitive advantage. Competitive advantages possessed will improve company performance.

Sixth, the company's performance can be improved by utilizing the company's internal resources, where the maximum utilization of the company's internal resources will improve the company's performance. Competitive advantages possessed will improve company performance.

\section{References}

[1] Abdullah, A.A., Hamdan, M.H., 2012. Internal Success Factor of Hotel Occupancy Rate. Int. J. Bus. Soc. Sci. 3, 199-218.

[2] Affendy, A.H., Asmat-Nizam, Abdul-Talib, Farid, M.., 2015. Entrepreneural Orientation effects on Market Orientation and SMEs Business Performance - A SEM Approach. Rev. Integr. Bus. Econ. 1, 336-346.

[3] Andriyanto, I., Nurjanah, 2015. STRATEGI KLASTER INDUSTRI MENGHADAPI PASAR GLOBAL. BISNIS 3, 85-114.

[4] Avlonitis, G.J., Salavou, H.E., 2007. Entrepreneurial orientation of SMEs, product innovativeness, and performance. J. Bus. Res. 60, 566-575.

[5] Barney, J., 1991. Firm Resources and Sustained Competitive Advantage. J. Manage. 17, 99-120.

[6] Boulianne, E., 2007. Revisiting fit between AIS design and performance with the analyzer strategic-type. Int. J. Account. Inf. Syst. 8, 1-16.

[7] Chandler, G.N., Hanks, S.H., 1994. Market attractiveness, resource-based capabilities, venture strategies, and venture performance. J. Bus. Ventur. 9, 331349.

[8] Clancy Dollinger, S.M., 1995. Identity styles and the five-factor model of personality. J. Res. Pers. 29, 475-479.

[9] Covin, J.G., Slevin, D.P., 1989. Strategic management of small firms in hostile and benign environments. Strateg. Manag. J. 10, 75-87.

[10] Etemad, H., 2009. Internationalization of Small and Medium-sized Enterprises: A Grounded Theoretical Framework and an Overview. Can. J. Adm. Sci. / Rev. Can. des Sci. l'Administration 21, 1-21.

[11] Fatoki, O., Oni, O., 2014. Financial Literacy Studies in South Africa: Current 
Literature and Research Opportunities. Mediterr. J. Soc. Sci.

[12] Gupta, S., Kumar, V., 2013. Sustainability as corporate culture of a brand for superior performance. J. World Bus. 48, 311-320.

[13] Heru Priyanto, S., 2012. Entrepreneurial and vocational learning in entrepreneurship education: Indonesian Non formal education perspective. Basic Res. J. Bus. Manag. Accounts 1, 30-36.

[14] Hoque, Z., 2004. A contingency model of the association between strategy, environmental uncertainty and performance measurement: Impact on organizational performance. Int. Bus. Rev. 13, 485-502.

[15] Irfan, M., Majeed, Y., Zaman, K., 2014. The Performance and Efficiency of Islamic Banking in South Asian Countries. Econ. Ser. Manag. 17, $223-237$.

[16] Ismaeel, M., Blaim, K., 2012. Toward applied Islamic business ethics: Responsible halal business. J. Manag. Dev. 31, 1090-1100.

[17] Jackson, S.E., Schuler, R.S., Jiang, K., 2014. An Aspirational Framework for Strategic Human Resource Management. Acad. Manag. Ann. 8, 1-56.

[18] Jantunen, A., Puumalainen, K., Saarenketo, S., Kyläheiko, K., 2005. Entrepreneurial orientation, dynamic capabilities and international performance. J. Int. Entrep. 3, 223-243.

[19] Jiang, K., Lepak, D.P., Han, K., Hong, Y., Kim, A., Winkler, A.L., 2012. Clarifying the construct of human resource systems: Relating human resource management to employee performance. Hum. Resour. Manag. Rev. 22, 73-85.

[20] Johnson, M.W., Christensen, C.M., Kagermann, H., 2008. Reinventing your business model. Harv. Bus. Rev. 86.

[21] Kozlenkova, I. V., Samaha, S.A., Palmatier, R.W., 2014. Resource-based theory in marketing. J. Acad. Mark. Sci. 42, 1-21.

[22] Kumar, V., Jones, E., Venkatesan, R., Leone, R.P., 2011. Is Market Orientation a Source of Sustainable Competitive Advantage or Simply the Cost of Competing? J. Mark. 75, 16-30.

[23] Kumar, V., Pansari, A., 2016. Competitive Advantage Through Engagement. J. Mark. Res. 53, 497-514.

[24] Kuratko, D.F., Hornsby, J.S., Covin, J.G., 2014. Diagnosing a firm's internal environment for corporate entrepreneurship. Bus. Horiz. 57, 37-47.

[25] Lechner, C., Gudmundsson, S.V., 2014. Entrepreneurial orientation, firm strategy and small firm performance. Int. Small Bus. J. 32, 36-60.

[26] Mariadoss, B.J., Tansuhaj, P.S., Mouri, N., 2011. Marketing capabilities and innovation-based strategies for environmental sustainability: An exploratory investigation of B2B firms. Ind. Mark. Manag. 40, 1305-1318.

[27] Miller, K.D., Pentland, B.T., Choi, S., 2012. Dynamics of Performing and Remembering Organizational Routines. J. Manag. Stud. 49, 1536-1558.

[28] Momoh, A., Roy, R., Shehab, E., 2010. Challenges in enterprise resource planning implementation: State-of-the-art. Bus. Process Manag. J. 16, 537-565.

[29] Morrison, A., Breen, J., Ali, S., 2003. Small Business Growth: Intention, Ability, and Opportunity. J. Small Bus. Manag. 41, 417-425.

[30] Mouzas, S., 2006. Efficiency versus effectiveness in business networks. J. Bus. Res. 59, 1124-1132.

[31] Othman, R., Arshad, R., Aris, N.A., Arif, S.M.M., 2015. Organizational Resources and Sustained Competitive Advantage of Cooperative Organizations in Malaysia. Procedia - Soc. Behav. Sci. 170, 120-127. 
[32] Porter, M.E., Kramer, M.R., 2006. Strategy \& society: The link between competitive advantage and corporate social responsibility. Harv. Bus. Rev. 84, 78-92.

[33] Prahalad, C.K., Hamel, G., June, M. a Y., Prahalad, C.K., Hamel, G., 1990. Prahalad, CK and G Hamel (1990). The Core Competence of the Corporation. Harvard Business Review, 68(3), 79-91. Harv. Bus. Rev.

[34] Purnomo, H., Achdiawan, R., Shantiko, B., Amin, S.M., Irawati, R.H., Wardell, D.A., 2016. Multi-stakeholder processes to strengthen policies for small and medium-scale forestry enterprises in Indonesia. Int. For. Rev. 18, 485-501.

[35] Ruekert, R.W., Walker, O.C.J., 1987. Marketing's Interaction with Other Functional Units: A Conceptual Framework and Empirical Evidence. J. Mark. 51, 1-19.

[36] Seddon, P.B., Constantinidis, D., Tamm, T., Dod, H., 2017. How does business analytics contribute to business value? Inf. Syst. J. 27, 237-269.

[37] Uhl-Bien, M., Marion, R., McKelvey, B., 2007. Complexity Leadership Theory: Shifting leadership from the industrial age to the knowledge era. Leadersh. Q.

[38] Witjaksono, M., 2009. Pembangunan Ekonomi dan Ekonomi Pembangunan: Telaah Istilah dan Orientasi dalam Konteks Studi Pembangunan. J. Ekon. Stud. Pembang. Univ. Malang 1, 1-12. 